\title{
Enzyme hydrolysate of silk protein suppresses tert-butyl hydroperoxide-induced hepatotoxicity by enhancing antioxidant activity in rats
}

\author{
Hyung Joo Suh ${ }^{1}$, Bobin Kang ${ }^{1}$, Chae-Young Kim ${ }^{1}$, Hyeon-Son Choi ${ }^{2 *}$ \\ ${ }^{1}$ Department of Food and Nutrition, Korea University, Seoul 02841, Korea \\ ${ }^{2}$ Department of Food Science and Technology, Seoul Women's University, Seoul 01797, Korea
}

\begin{abstract}
The purpose of current study is to investigate the beneficial effect of enzyme (Alcalase) hydrolysates of silk protein in rat. Alcalase-treated silk protein hydrolysate (ATSH) itself did not show any cytotoxicity on the hepatic tissues and blood biochemistry, similar to the normal condition. ATSH played a protective role in tert-butyl hydroperoxide ( $t$-BHP)-induced hepatotoxicity and liver damage. The values of AST (aspartate aminotransferase) and ALT (alanine aminotransferase), which are the indicators of the liver function, were effectively alleviated with the ATSH treatment in a dose dependent manner. The level of Lactate dehydrogenase (LDH) and Malondialdehyde (MDA), which were increased with $t$-BHP treatment, were significantly reduced by ATSH. High dose of ATSH ( $2 \mathrm{~g} / \mathrm{kg})$ reduced the $t$-BHP-induced LDH release by $\mathbf{4 8 \%}$. Antioxidant and antioxidant enzymes in liver cells were significantly increased by ATSH treatment in their level and activities. ATSH (2 g/kg) increased glutathione (GSH), an intracelluar antioxidant, by 2.5 -fold compared with the $t$-BHP treated group. The activities of glutathione-s-transferase (GST), superoxide dismutase (SOD), and catalase were also elevated by $38 \%, 60 \%$, and 45\%, respectively, with ATSH (2 g/kg) treatment. The antioxidative effect of ATSH was recapitulated to the protection from $t$-BHP induced liver damages in hematoxylin and eosin (H\&E) staining. Thus, ATSH might be used as a hepatoprotective agent.
\end{abstract}

Key words : silk proteins hydrolysate, hepatoprotective effect, liver damage, tert-butyl hydroperoxide, antioxidant enzymes

\section{Introduction}

Silk peptide is a high molecular substance from silk thread, in which the low molecules such as amino acids connected with each other. It consisted of amino acids which are necessary to growth and development of cells for the normal functions of body (1). Cocoon, a major source of silk peptide, is composed of the fibroin and sericin with 3:1 ratio. Fibroin is obtained from external parts of raw silk thread with a removal of sericin, and one ray of silk contains about 40,000 amino acids $(1,2)$. Fibroin has been known to be enriched in glycine and alanine compared with the other food source

*Corresponding author. E-mail : hschoi@swu.ac.kr

Phone : 82-2-970-5683, Fax : 82-2-970-5977

Received 31 May 2017; Revised 19 July 2017; Accepted 20 July 2017.

Copyright (c) The Korean Society of Food Preservation. All rights reserved. like milk and egg, and contains $6 \%$ essential amino acids $(1,2)$. Silk protein has been known to have superiority in terms of digestion and absorption compared with meatderived proteins, and accompanied with minerals such as calcium and iron in absorption (1,2). Many studies have been performed on silk peptide functionalities such as antioxidative stress, cholesterol lowering, hypoglycemic, and anti-inflammatory effects (3-6).

Liver plays an important role in metabolism, synthesis, storage, bioconversion of biomolecule in the body. In particular, it plays a crucial part in biosynthesis and oxidation of carbohydrates, proteins, lipids, nucleic acids, and vitamins, producing bile juice to help digestion and absorption of lipids, and bioconverting endogenous toxic substances to the form for easier excretion in kidney via conjugational action. In glucose metabolism, it stores surplus energy source in glycogen form (7).

Liver can be damaged from various cases including alcohol, 
smoking, virus infection, intoxication, nutrition imbalance, and stresses in complex modern society (8). In particular, oxidative stress is one of the main reasons leading to liver damage in the body. Reactive oxygen species (ROS), free radicals which are enhanced by oxidative stress, attack biomolecule via randomized reaction to cause the various diseases such as aging, inflammation, cancer, and artery sclerosis $(9,10)$. Cell membrane, which has abundant polyunsaturated fatty acids, is a major target for the lipid peroxidation by free radicals (11). Excessive production of lipid peroxide by free radicals leads to the cellular damages, which cause the loss of structure and function in cell organs (11). The level of ROS (or free radicals) is normally controlled by protective mechanism of the body. The system regulating ROS includes protective enzymes and antioxidant molecules (12). In particular, antioxidant enzymes such as glutathiones-transferase (GST), superoxide dismutase (SOD), and catalase play an important role in scavenging ROS (13-15). Thus, activity of these enzymes in cells is an crucial biomarker in controlling ROS level or cellular detoxification (16). Liver damage or degeneration of liver function is an important health issue for people to have to overcome in modern society orienting wellbeing culture. Liver diseases including obstacle of liver function are continuously increasing, resulting in negative impact on in economy and society (17). Therefore, many studies on materials or sources to fortify liver health are necessary for the improvement or prevention of liver diseases in national and social levels. In terms of relatively fewer side effect, research and development on the agent helpful in liver health have been necessarily performed by focusing on phytochemical derived from natural products. We previously investigated protective effects of acid hydrolysate on the liver damage (18). In current study, enzyme hydrolysate have been prepared using Alcalase from silk protein, and the protective effect against chemical-induced liver cytotoxicity was examined with antioxidant activity.

\section{Materials and Methods}

\section{Preparation of enzyme hydrolysate}

Cocoon (200 g), which was cut by $3-4 \mathrm{~cm}$, was boiled in $0.5 \% \mathrm{Na}_{2} \mathrm{CO}_{3}$ for $30 \mathrm{~min}$ to remove the impurities. Cocoon samples were filtered with Whatman paper (Whatman ${ }^{\circledR}$ qualitative filter paper, Grade 1), and salts were removed by incubating at $\mathrm{pH} 5.8 \pm 0.1$ until salt concentration was $0.5 \%$. Precipitated samples (100 g) were digested by incubation at $60^{\circ} \mathrm{C}$ and $\mathrm{pH} 7$ with Alcalase (Novozyme, San Francisco, CA, USA) for $6 \mathrm{~h}$. Enzyme was deactivated by boiling at $100^{\circ} \mathrm{C}$ for $5 \mathrm{~min}$, and samples were concentrated by an evaporator (Rotavapor ${ }^{\circledR}$ R-300, BUCHI, Flawil, Swizerland), after which samples were freeze dried. It was used as alkaline treated silk peptide hydrolysate (ATSH) in subsequent experiments.

\section{Animal maintenance}

Sprague-Dawley (SD) rats (8 weeks of age) were divided with 6 groups ( $n=5$ per group) by random sampling; the group administrated with saline instead of ATSH (NC, normal control), the group treated with only ATSH $(2 \mathrm{~g} / \mathrm{kg})$ (NC-2), the group treated with tert-BHP to induce the hepatocytotoxicity (TC, $t$-BHP-treated control group), the groups administrated with ATSH $0.5 \mathrm{~g} / \mathrm{kg}, 1.0 \mathrm{~g} / \mathrm{kg}$ and 2.0 $\mathrm{g} / \mathrm{kg}$ (ATSH groups). Samples $(2 \mathrm{~mL}$ ) from each groups were orally administrated once a day for 7 days (19). The animals were maintained at $50 \pm 5 \%$ of relative humidity, $21 \pm 2{ }^{\circ} \mathrm{C}$ of temperatures with $12 \mathrm{~h}$ (dark)/12 h (light) cycle, and allow them to adjust to a controlled environment at least 1 week prior to use. All experiments were performed according to the rules and regulations of Animal Ethics Committee, Korea University (KUIACUC-2010-141). Rats were sacrificed using $\mathrm{CO}_{2}$ after fasting for $18 \mathrm{~h}$ on end of experiment day.

\section{Biochemical and hematological analysis}

Blood was removed by cardiac puncture after sacrifice. Serum aspartate aminotransferase (AST), alanine aminotransferase (ALT), total cholesterol (T.Chol), total protein, glucose, alkaline phosphatase (ALP), lactate dehydrogenase (LDH), albumin and glucose levels were measured using a FUJI DRI-CHEM 3500 system (Fuji Photo Film Co., Osaka, Japan). For hematological analysis, blood samples were sent to GC Labs (Yongin, Korea), and white blood cell (WBC), red blood cell count $(\mathrm{RBC})$, hemoglobin concentration $(\mathrm{Hb})$, hematocrit $(\mathrm{HCt})$, mean corpuscular hemoglobin volume (MCV), mean corpuscular hemoglobin concentration (MCHC), and platelet (PLT) were analyzed.

\section{Histopathological evaluation}

Liver was removed from the rats after sacrifice, and fixed in $1.2 \mathrm{M}$ formaldehyde solution. The samples were dehydrated in ethyl alcohol (Sigma-Aldrich Co., St. Louis, MO, USA) and embedded in paraffin. Liver tissue sections were cut $(<5$ um), mounted on glass slides and counter-stained with the hematoxylin and eosin (H\&E) dye for light microscopy 
observation. Stained liver sections were analyzed and photographed under microscope for observation of histopathologies.

\section{GSH analysis}

GSH level was examined according to the Reed's method (20). Liver (1 g) was homogenated with $50 \mathrm{mM}$ N-ethylmaleimide (NEM, $9 \mathrm{~mL}$ ) at $4{ }^{\circ} \mathrm{C}$, and centrifuged at $600 \times g$ for $10 \mathrm{~min}$. The upper homogenates $(0.1 \mathrm{~mL})$ and NEM $1 \mathrm{~mL}$ were mixed, and $60 \%$ perchloric acid was added to adjust to $5 \%$ concentration, after which centrifugation was performed at $1,000 \times g$ for $1 \mathrm{~min}$. The supernatant $(1 \mathrm{~mL})$ was mixed $50 \mathrm{mM}$ iodoacetate (IAA, $0.1 \mathrm{~mL}$ ) and $1 \mathrm{M}$ potassium hydrogen carbonate $(0.1 \mathrm{~mL})$, and incubated at dark place for $20 \mathrm{~min}$. Same volume of 3\% fluoro-2,4dinitrobenzene (FDNB) was added and stood for overnight. Then, it was centrifuged at next day and the supernatant was used for analysis. GSH and GSSG (Sigma-Aldrich Co.) were used as standards. The HPLC analytical conditions are following; solvent A contain the mixture of methanol and water $(4: 1(\mathrm{v}: \mathrm{v}))$, solvent B includes the mixture of sodium acetate trihydrate $(272 \mathrm{~g}), 122 \mathrm{~mL}$ of distilled water, 378 $\mathrm{mL}$ of glacial acetic acid $(200 \mathrm{~mL})$, and Solvent A $(800 \mathrm{~mL})$. The analysis was performed during the gradients of Solvent B (95\% to $70 \%, 5 \%$ to $30 \%$ ) for $60 \mathrm{~min}$. Used colomun was OptimaPak $\mathrm{NH}_{2} 5 \mathrm{um}(4.6 \times 250 \mathrm{~mm}$, Oregon City, OR, USA) with the elution rate of $1 \mathrm{~mL} / \mathrm{min}$ and $0.1 \mathrm{~mL}$ of injection volume. GSH content was detected at $365 \mathrm{~nm}$.

\section{Determination of antioxidant enzyme activities}

Liver tissue $(1 \mathrm{~g})$ was ground in $50 \mathrm{mM}$ potassium

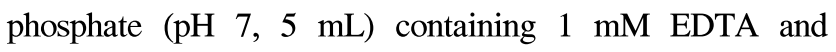
centrifuged at $10,000 \times \mathrm{g}$ at $4^{\circ} \mathrm{C}$ for $20 \mathrm{~min}$. The supernatant was used for the enzymatic reactions. For GST activity, The reactions were carried out with 1 to $10 \mathrm{mg}$ of the cytosolic protein, $1 \mathrm{mM}$ 1-chloro-2, 4-dinitrobenzene (CDNB, GST substrate), $1 \mathrm{mM}$ reduced $\mathrm{GSH}$, and $100 \mathrm{mM}$ potassium phosphate buffer $(\mathrm{pH} 7.5)$ at $37^{\circ} \mathrm{C}$. An assay mixture without the enzyme served as a control. The conjugation of CDNB with GSH was monitored at $340 \mathrm{~nm}$ (21). CAT activity was measured according to the method described by Aebi et al. (22). Liver homogenates (10 mg protein, $50 \mathrm{~mL}$ ) were mixed with $0.65 \mathrm{~mL}$ of $50 \mathrm{mM}$ potassium phosphate buffer. Hydrogen peroxide $\left(\mathrm{H}_{2} \mathrm{O}_{2}, 30 \mathrm{mM}, 0.3 \mathrm{~mL}\right)$ was added to the mixture as a substrate. The color change was monitored by measuring the absorbance at $240 \mathrm{~nm}$ for $3 \mathrm{~min}$ at 30 $\mathrm{s}$ intervals. The SOD activity was determined using the xanthine-xanthine oxidase 3-(4-iodophenyl)-2-(4-nitrophenyl)5-phenyltetrazolium chloride (INT) system, as previously described (23). The reaction mixture containing $0.05 \mathrm{mM}$ xanthine, $0.025 \mathrm{mM}$ INT, $1 \mathrm{mM}$ EDTA, and $0.1 \mathrm{~mL}$ of the liver supernatants was mixed with $0.1 \mathrm{~mL}$ xanthine oxidase ( 80 units per $\mathrm{mL}$ ). The change in absorbance in $20 \mathrm{~min}$ was monitored at $450 \mathrm{~nm}$ (23). All enzyme activities were expressed as units per $\mathrm{mg}$ protein.

\section{Malondialdehyde (MDA) analysis}

Liver $(1 \mathrm{~g})$ was homogenized with $1.15 \% \mathrm{KCl}$ solution $(9 \mathrm{~mL})$ on ice. The homogenates were centrifuged at 600 $\times g$ for $10 \mathrm{~min}$ at $4^{\circ} \mathrm{C}$ to remove the tissue debris. The supernatant $(0.1 \mathrm{~mL})$ was mixed with $8.1 \%$ sodium dodecyl sulfate (SDS, $0.2 \mathrm{~mL}$ ), and then $20 \%$ acetic acid $(1.5 \mathrm{~mL})$ and $0.8 \%$ thiobarbituric acid (TBA, $1.5 \mathrm{~mL}$ ) were added. The mixture was incubated for $60 \mathrm{~min}$ at $95^{\circ} \mathrm{C}$. Distilled water $(1 \mathrm{~mL}$ ) and solvent solution (butanol:pyridine=15:1, $5 \mathrm{~mL}$ ) was added, and centrifuged at $600 \times g$ for $10 \mathrm{~min}$. The supernatant was examined at excitation $515 \mathrm{~nm} / \mathrm{emission} 552$ nm. 1,1,3,3-Tetramethoxypropane was used as a standard (24).

\section{Statistical analysis}

All statistical analyses were executed using the Statistical Package for Social Sciences version 12.0 (SPSS Inc., Chicago, IL, USA). Differences among groups were determined by one-way ANOVA and Tukey's multiple comparison tests. Statistic values of $\mathrm{p}<0.05$ were considered significantly different. All data are reported as means \pm SD.

\section{Results and Discussion}

\section{Biochemical test of Blood}

ATSH-treated group showed a similar result compared with the control group, indicating that ATSH treatment did not cause any side effect including cytotoxicity to animals (Table 1). However, $t$ BHP treatment showed a significant increase in AST and ALT, biomarkers involved in the liver cells and their functions. This result indicated that $t$-BHP caused the destruction and necrosis of liver cells. Such an increase of AST and ALT by $t$-BHP effectively reduced by ATSH treatment. High dose of ATSH $(2 \mathrm{~g} / \mathrm{kg})$ decreased the level of AST and ALT by $33 \%$ and $48 \%$, respectively, compared with $t$-BHP treatment. This data showed that silk protein hydrolysate effectively suppressed the liver damage induced 
Table 1. Blood biochemical test in ATSH and $t$-BHP-treated rats

\begin{tabular}{|c|c|c|c|c|c|c|}
\hline \multirow{2}{*}{ Item $^{1)}$} & \multicolumn{2}{|c|}{ No $t$-BHP } & \multicolumn{4}{|c|}{$t \mathrm{BHP}(0.2 \mathrm{mM} / \mathrm{kg})+\mathrm{ATSH}(\mathrm{g} / \mathrm{kg})$} \\
\hline & $0^{2)}$ & $2^{3)}$ & $0^{4)}$ & 0.5 & 1 & 2 \\
\hline T.Protein $(\mathrm{g} / \mathrm{dL})$ & $6.3 \pm 0.32^{\mathrm{ns} 5)}$ & $6.5 \pm 0.10^{\mathrm{ns}}$ & $5.8 \pm 0.23^{\text {ns }}$ & $6.2 \pm 0.15^{\mathrm{ns}}$ & $6.4 \pm 0.17^{\mathrm{ns}}$ & $6.1 \pm 0.21^{\mathrm{ns}}$ \\
\hline Albumin $(\mathrm{g} / \mathrm{dL})$ & $3.7 \pm 0.15^{\mathrm{ns}}$ & $3.8 \pm 0.09^{\mathrm{ns}}$ & $3.9 \pm 0.12^{\mathrm{ns}}$ & $3.9 \pm 0.08^{\mathrm{ns}}$ & $3.9 \pm 0.154^{\mathrm{s}}$ & $3.9 \pm 0.14^{\mathrm{ns}}$ \\
\hline ALP (U/L) & $283.6 \pm 32.20^{\mathrm{ns}}$ & $285.1 \pm 33.21^{\mathrm{ns}}$ & $273.1 \pm 22.13^{\text {ns }}$ & $265.0 \pm 24.65^{\mathrm{ns}}$ & $277.2 \pm 31.50^{\mathrm{ns}}$ & $291.6 \pm 36.73^{\text {ns }}$ \\
\hline AST (U/L) & $123.5 \pm 7.83^{\mathrm{e}}$ & $110.5 \pm 2.97^{\mathrm{e}}$ & $209.3 \pm 13.82^{\mathrm{a}}$ & $189.8 \pm 7.92^{b}$ & $150.8 \pm 15.70^{c}$ & $140.2 \pm 7.68^{\mathrm{d}}$ \\
\hline ALT (U/L) & $45.2 \pm 1.71^{\mathrm{c}}$ & $41.0 \pm 0.63^{\mathrm{d}}$ & $94.1 \pm 4.87^{\mathrm{a}}$ & $84.5 \pm 10.91^{\mathrm{a}}$ & $62.1 \pm 3.85^{\mathrm{b}}$ & $48.8 \pm 5.31^{\mathrm{c}}$ \\
\hline LDH (U/L) & $1872.0 \pm 110.42^{\mathrm{d}}$ & $1452.3 \pm 135.93^{\mathrm{e}}$ & $4557.6 \pm 382.32^{\mathrm{a}}$ & $3820.4 \pm 333.24^{b}$ & $2671.0 \pm 295.00^{\mathrm{c}}$ & $2363.5 \pm 255.14^{\mathrm{c}}$ \\
\hline T.Chol (mg/dL) & $52.3 \pm 4.24^{\mathrm{ab}}$ & $49.05 \pm 4.20^{\mathrm{b}}$ & $67.4 \pm 5.33^{\mathrm{a}}$ & $58.3 \pm 3.43^{\mathrm{a}}$ & $49.0 \pm 1.15^{\mathrm{b}}$ & $53.2 \pm 2.65^{\mathrm{ab}}$ \\
\hline Glucose (g/dL) & $81.0 \pm 10.23^{\mathrm{ns}}$ & $85.0 \pm 4.94^{\mathrm{ns}}$ & $97.3 \pm 9.71^{\mathrm{ns}}$ & $71.8 \pm 9.91^{\mathrm{ns}}$ & $86.8 \pm 3.31^{\mathrm{ns}}$ & $68.4 \pm 4.34^{\mathrm{ns}}$ \\
\hline
\end{tabular}

${ }^{1)}$ T.Protein, total protein; T.Chol, total cholesterol.

${ }^{2)}$ normal control (NC).

${ }^{33} \mathrm{NC}-2$ (normal control+2 g of ATSH)

${ }^{4)} \mathrm{TC}(t$-BHP-treated control).

${ }^{5} \mathrm{~ns}$, Means $\pm \mathrm{SD}(\mathrm{n}=5)$ within each column followed are not significantly different $(\mathrm{p}<0.05)$.

by $t$-BHP. LDH, a indicator of cell cytotoxicity, was greatly reduced by ATSH treatment. ATSH $(2 \mathrm{~g} / \mathrm{kg}$ ) suppressed the $t$-BHP-induced LDH release from liver tissue by $48 \%$. LDH, a glycolytic enzyme, which widely exist in most of tissues including heart, liver, kidney, has been known to be released with AST and ALT by tissue damages, and increased in acute early hepatitis condition (25). Therefore, This result indicated that ATSH protects the liver cell from the cytotoxic condition. Total cholesterol level, which was enhanced by $t$ BHP, was also shown to be slightly decreased by ATSH treatment $(\sim 20 \%)$. However, in total protein, albumin, and glucose, significant changes from tested groups were not observed. In addition, hematological indexes including WBC, $\mathrm{RBC}, \mathrm{Hb}$,
$\mathrm{HCt}, \mathrm{MCV}, \mathrm{MCHC}$, and PLT did not exhibit any significant changes between ATSH and $t$-BHP-treated groups (Table 2). These results showed a similar trend to our previous study which investigated acid hydrolysate of silk protein (18). However, suppressive effect of ATSH on AST and ALT levels was observed to be better than that of acid hydolysates of silk protein, which showed $26 \%$ and $39 \%$, respectively. Inhibition of LDH release was observed to be higher in ATSH treatment $(48 \%)$ than in acid hydrolysate $(29 \%)$ (Table 1) (18). ATSH treatment further exhibited inhibitory effect on the cholesterol level of blood unlike acid hydrolysate. This discrepancy was due to the difference of peptide composition be ween enzyme and acid hydrolysate. Various protein

Table 2. Blood test of ATSH and $t$-BHP-treated rats

\begin{tabular}{|c|c|c|c|c|c|c|}
\hline \multirow{2}{*}{ Item $^{1)}$} & \multicolumn{2}{|c|}{ No $t$-BHP } & \multicolumn{4}{|c|}{$t$ BHP $(0.2 \mathrm{mM} / \mathrm{kg})+\mathrm{ATSH}(\mathrm{g} / \mathrm{kg})$} \\
\hline & $0^{2)}$ & $2^{3)}$ & $0^{4)}$ & 0.5 & 1 & 2 \\
\hline $\mathrm{RBC}\left(10^{6} / \mathrm{mm}^{3}\right)$ & $8.2 \pm 0.18^{5 \mathrm{~ns} 6)}$ & $8.0 \pm 0.52^{\mathrm{ns}}$ & $7.8 \pm 0.23^{\text {ns }}$ & $7.6 \pm 0.25^{\mathrm{ns}}$ & $7.7 \pm 0.31^{\text {ns }}$ & $7.9 \pm 0.42^{\mathrm{ns}}$ \\
\hline WBC $\left(10^{3} / \mathrm{mm}^{3}\right)$ & $7.3 \pm 1.05^{\mathrm{ns}}$ & $7.0 \pm 0.78^{\mathrm{ns}}$ & $6.3 \pm 0.95^{\mathrm{ns}}$ & $8.7 \pm 0.38^{\mathrm{ns}}$ & $8.7 \pm 1.18^{\mathrm{ns}}$ & $8.7 \pm 0.29^{\mathrm{ns}}$ \\
\hline $\mathrm{HCt}(\%)$ & $51.9 \pm 0.32^{\mathrm{ns}}$ & $52.6 \pm 1.42^{\mathrm{ns}}$ & $52.1 \pm 0.47^{\mathrm{ns}}$ & $51.3 \pm 0.66^{\mathrm{ns}}$ & $52.0 \pm 0.42^{\mathrm{ns}}$ & $50.7 \pm 2.10^{\text {ns }}$ \\
\hline $\mathrm{Hb}(\mathrm{g} / \mathrm{dL})$ & $13.9 \pm 0.40^{\mathrm{ns}}$ & $14.5 \pm 0.20^{\mathrm{ns}}$ & $13.7 \pm 0.33^{\text {ns }}$ & $14.3 \pm 0.25^{\mathrm{ns}}$ & $14.4 \pm 0.14^{\mathrm{ns}}$ & $14.3 \pm 0.46^{\mathrm{ns}}$ \\
\hline MCV (fL) & $68.7 \pm 1.54^{\mathrm{ns}}$ & $69.5 \pm 0.53^{\mathrm{ns}}$ & $71.8 \pm 0.76^{\mathrm{ns}}$ & $71.3 \pm 0.55^{\mathrm{ns}}$ & $71.9 \pm 1.19^{\mathrm{ns}}$ & $70.4 \pm 1.7^{\mathrm{ns}}$ \\
\hline $\mathrm{MCH}(\mathrm{pg})$ & $19.2 \pm 0.23^{\text {ns }}$ & $19.7 \pm 0.11^{\mathrm{ns}}$ & $19.8 \pm 0.17^{\mathrm{ns}}$ & $19.9 \pm 0.20^{\mathrm{ns}}$ & $19.9 \pm 0.17^{\mathrm{ns}}$ & $19.9 \pm 0.18^{\text {ns }}$ \\
\hline $\mathrm{MCHC}(\mathrm{g} / \mathrm{dL})$ & $28.3 \pm 0.58^{\mathrm{ns}}$ & $28.4 \pm 0.16^{\mathrm{ns}}$ & $27.3 \pm 0.34^{\mathrm{ns}}$ & $27.9 \pm 0.35^{\text {ns }}$ & $27.7 \pm 0.21^{\mathrm{ns}}$ & $28.3 \pm 0.48^{\text {ns }}$ \\
\hline PLT $\left(10^{3} / \mathrm{mm}^{3}\right)$ & $677.8 \pm 153.00^{\mathrm{ns}}$ & $875.8 \pm 119.10^{\mathrm{ns}}$ & $819.5 \pm 43.58^{\mathrm{ns}}$ & $838.7 \pm 101.67^{\mathrm{ns}}$ & $726 \pm 50.36^{\text {ns }}$ & $771.5 \pm 70.89^{\mathrm{ns}}$ \\
\hline
\end{tabular}

${ }^{1)} \mathrm{RBC}$, red blood cell count; WBC, white blood cell count; HCt, hematocrit; Hb, hemoglobin concentration; MCV, mean corpuscular hemoglobin volume; MCHC, mean corpuscular hemoglobin concentration; PLT, platelet.

${ }^{2)}$ normal control (NC).

${ }^{3)} \mathrm{NC}-2$ (normal control+2 $\mathrm{g}$ of ATSH).

${ }^{4)} \mathrm{TC}(t$-BHP-treated control).

${ }^{5)}$ Values are expressed as means \pm SD for 5 rats. Values not sharing the same letter are significantly different, $\mathrm{p}<0.05$.

6) ns, not significant. 
hydrolysate or peptides were shown to have a beneficial effect on liver health. Potato-derived peptides suppressed the necrosis of live cell induced by high fat diet (26). Chung et al. reported that corn gluten hydrolysate enriched with branched chain amino acid (BCAA) protects liver from alcohol-induced hepatocytocity (27). A recent study showed that a fish protein hydrolysate protects liver from alcoholinduced oxidative stress in rat (28).

\section{Effect of ATSH on malondialdehyde in liver and blood}

Oxidative stress causes the production of various radicals and their reaction products (29). Lipid peroxidation is occurred from excessive oxidation of polyunsaturated fatty acid in cell membrane by free radicals, and such an polyunsaturated fatty acid is degraded to be malondialdehyde (MDA) via oxidation process (18). Thus, MDA is another indicator of oxidative stress in cells. ATSH itself slightly decreased the spontaneous production of MDA in normal group, and $t$-BHP increased the level in liver and blood by $45 \%$ and $25 \%$, respectively (Fig. 1). These increases of MDA in liver and blood were significantly reduced by ATSH treatment. High dose of ATSH $(2 \mathrm{~g} / \mathrm{kg})$ decreased the MDA levels by $37 \%$ in liver and $20 \%$ in blood, respectively, compared with the $t$-BHP treatment. This result showed that ATSH effectively suppressed the production of lipid peroxide induced by oxidative stress. ATSH-derived inhibition of MDA was more distinctive in liver than blood. This result is considered that liver is the main site to detoxify the toxic chemical. This study showed a little difference from the previous study, in which MDA level in blood was not significantly changed by silk protein hydrolysate (18). Thus, enzyme hydrolysate in current study is thought to be better than acid hydrolysate in MDA suppression. The ATSHmediated MDA suppression is shown to be due to the inhibition of $t$-BHP-induced oxidative stress, which can cause the oxidation of polyunsaturated fatty acid. Several protein hydrolysate have been known to inhibit MDA production. Han et al. reported the suppressive effect of the hydrolysate of rice byproduct on MDA production (30). Germinated and fermented soybean extract was also reported to effectively inhibit MDA production in rat liver (16). A recent study showed that enzymatic hydrolysate from the Schizochytrium controls the MDA production in alcohol- induced liver inured mice (31).

\section{Effect of ATSH on antioxidants of liver}

To determine whether ATSH-mediated MDA production is involved in the molecules responsible for the ROS regulation, glutathione (GSH) and antioxidant enzymes including glutathione-s-transferase (GST), superoxide dismutase (SOD), and catalase from liver were examined in the content and activities. GSH is a potent antioxidant responsible for a crucial role in the detoxification, immune function of the body (32). In normal condition, GSH level was increased by around $45 \%$ with ATSH treatment $(2 \mathrm{~g} / \mathrm{kg})$ (Fig. 2A), indicating that ATSH can suppress the reduction of GSH resulted from the spontaneous metabolic state. $t$-BHP treatment led to the reduction of GSH by $64 \%$ compared with the normal group. $t$ BHP-induced reduction of GSH was
A

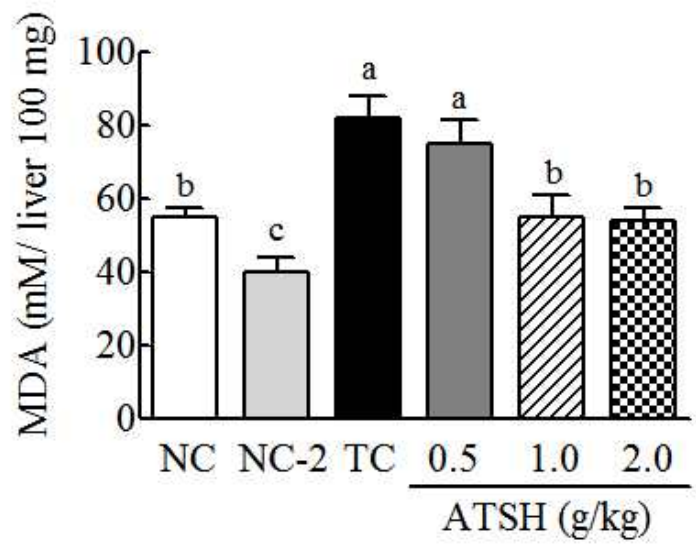

B

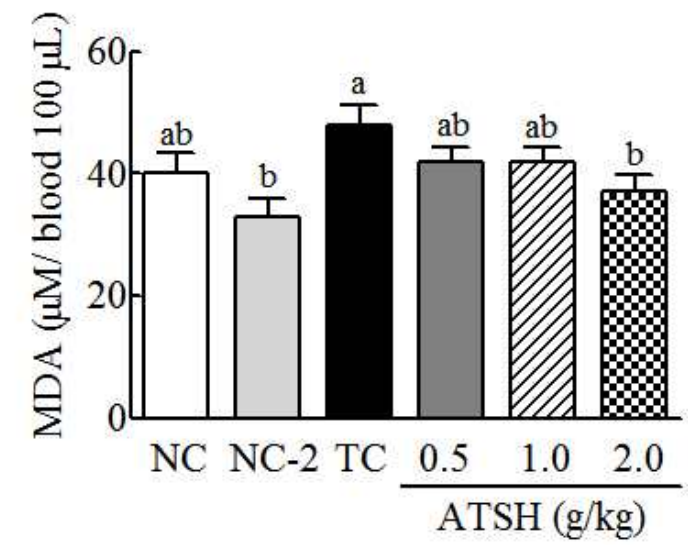

Fig. 1. Effect of ATSH on MDA production in $t$-BHP-treated SD rat liver (A) and blood (B).

$\mathrm{NC}$, normal control (no treatment); NC-2, normal control $+2 \mathrm{~g}$ of ATSH; TC, $t$-BHP-treated control

Values are expressed as means \pm SD for 5 rats. Different letters indicate significant differences at $p<0.05$. 
reversed by ATSH treatment in a dose dependent way (Fig. 2A). High dose of ATSH ( $2 \mathrm{~g} / \mathrm{kg}$ ) increased the GSH level by over 3-fold compared with the $t$-BHP treated group. This result showed that ATSH effectively suppresses the reduction of GSH by $t$-BHP. Nasri et al. reported that goby protein hydrolysate ameliorates the reduction of GSH induced by high fat and high sugar diet (33). Discorin, which is derived from the yam, was also shown to increase the GSH to control the oxidative stress (34). Pacheco et al. prepared different enzyme hydrolysate using pancreatin, protamex, and alcalase from whey protein, and observed that hydrolysate treated with pancreatin and protamex more effectively stimulated GSH production (35). Considering the effect of alcalase-treated silk protein in current study, protein source is thought to be important to produce the active peptides via enzymes. In antioxidant enzymes, ATSH was shown to increase the enzymatic activities (Fig. 2B-D). These enzyme activities were decreased with $t$-BHP treatment. The activity of SOD reduced by $28 \%$ with $t$-BHP treatment (Fig. 2C). Such a reduction of enzyme activities by $t$-BHP was reversed by ATSH treatment in a dose dependent manner. High dose of ATSH $(2 \mathrm{~g} / \mathrm{kg})$ enhanced activities of GST, SOD, and catalase by $50 \%, 65 \%$, and $60 \%$, respectively. This result showed that ATSH increased antioxidant capacities by activating antioxidant enzymes in liver. This data supports the ATSH-mediated reduction of MDA (Fig.1). This ATSHmediated increase of antioxidant enzyme activity is considered to control oxidative stress, which causes MDA production, and thereby suppress the liver cytotoxicity or damages. Kamoun et al. reported that fish sardinelle protein hydrolsates elevated the activities of antioxidant enzyme such as SOD, catalase, and glutathione peroxidase in rat with alcohol-induced oxidative stress (28). Kim et al. showed that the increase of antioxidant enzyme activity by soybean extract
A
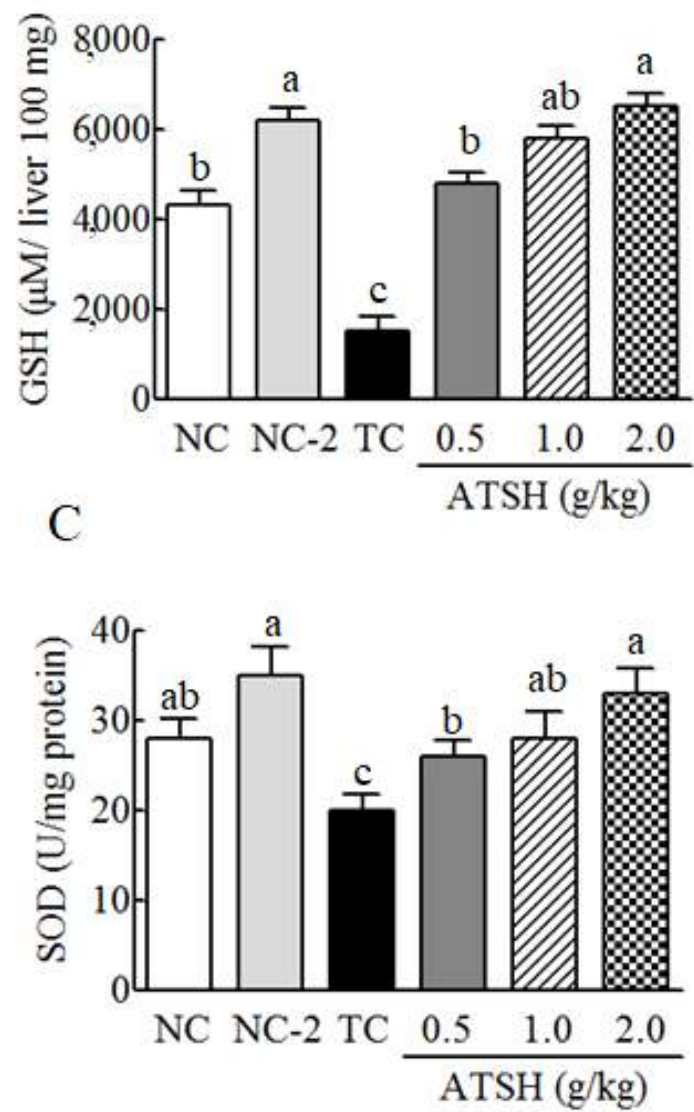

B
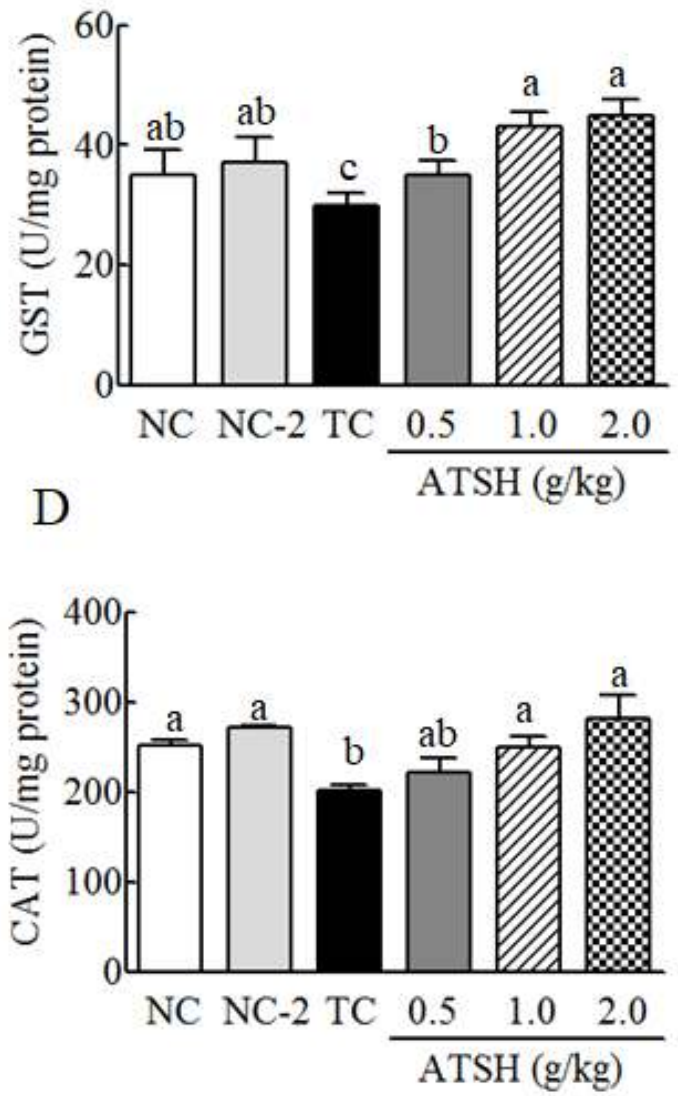

Fig. 2. Effect of ATSH on glutathione content (A) and antioxidant enzyme activity (B-D) in $t$-BHP-treated SD rat liver. $\mathrm{NC}$, normal control (no treatment); NC-2, normal control $+2 \mathrm{~g}$ of ATSH; TC, $t$-BHP-treated control. Values are expressed as means \pm SD for 5 rats. Different letters indicate significant differences at $\mathrm{p}<0.05$. 
was due to up-regulation of the corresponding genes (16). The increase of these antioxidant enzymes in cells is known to reduce oxidative stress by controlling the intracellular reactive oxygen species (ROS), which is cytotoxic to the cellular molecules $(10,15)$. Therefore, ATSH treatment is expected to reduce ROS level to protect liver from $t$-BHP-induced liver damages. ATSH-mediated control of ROS is considered to be achieved via regulation of activities of these antioxidant enzymes rather than direct ROS scavenging action.

\section{Effect of ATSH on histology of liver}

To investigate whether ATSH affects the histologic change of liver induced by $t$-BHP, hematoxylin and eosin (H\&E) staining was performed in the presence or absence of ATSH. The necrosis of cell accompanies by expansion of mitochondria, destruction of small cellular organs, lesion of cell membrane, synchysis of lysosome, causing the intracellular contents spilled out with inflammation (36,37). $\mathrm{H} \& \mathrm{E}$ staining showed significant change of live tissues in $t$-BHP and ATSH treatments (Fig. 3). Normal or only ATSH-treated group did not exhibit any lesion of cell tissue such as necrosis of liver cell or inflammatory infiltration, showing distinct morphology of cytoplasm and circle nucleus
(Fig. 3A, B). However, in $t$-BHP-treated group, the lesion and necrosis of tissues and cells were observed with white color comparing to surroundings (Fig. 3C). The co-treatment of ATSH and $t$-BHP turned around the necrosis of the cells seen in the $t$-BHP only treatment in a dose dependent manner (Fig. 3D-F). The histology of high dose ATSH was shown to be similar to that of normal group. This result showed $t$-BHP-induced lesion of liver tissue was suppressed by ATSH treatments, and ATSH protects liver from the $t$-BHP-induced damages. These protective effects of ATSH have a thread of connection with elevated activities of liver antioxidant enzymes and lowered AST and ALT values. Similar result was observed in acid hydrolysate from silk protein in the previous study (18). The effect of ATSH seems to be more obvious than acid hydrolysate, but exact comparison would be evaluated in the same experimental condition. Han et al. showed that rice byproduct fraction (SRP-70) alleviates the damage of liver tissue induced by $t$-BHP (30). SRP-70 was shown to contain peptides below molecular weight 600 via mass spectrometer analysis (30). Current study did not deal with the active peptides or peptide composition, responsible for the liver protective effect. When peptide sequences are discovered via compositional and molecular analyses in further study, active peptides would be more easily prepared
A

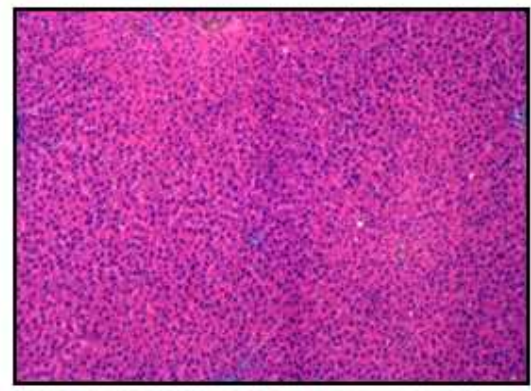

D

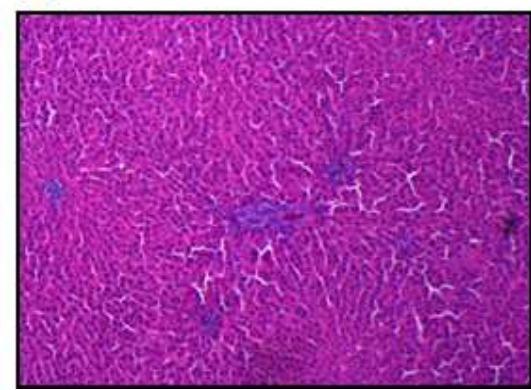

B

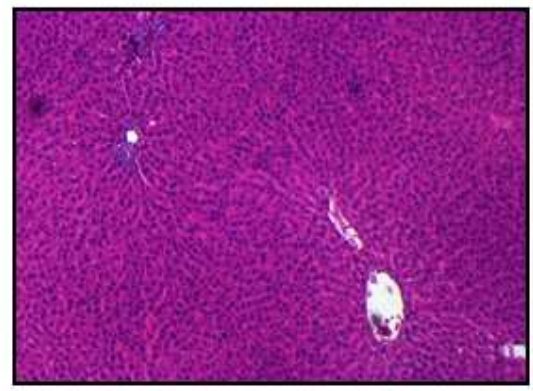

E

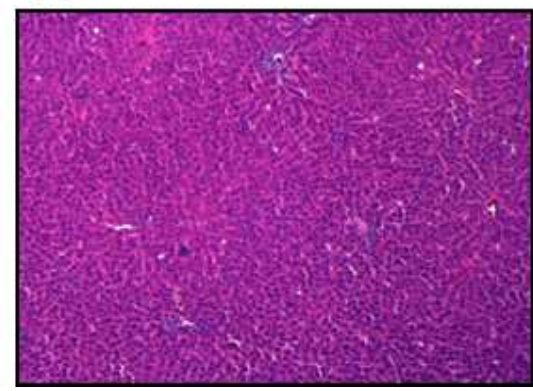

$\mathrm{C}$

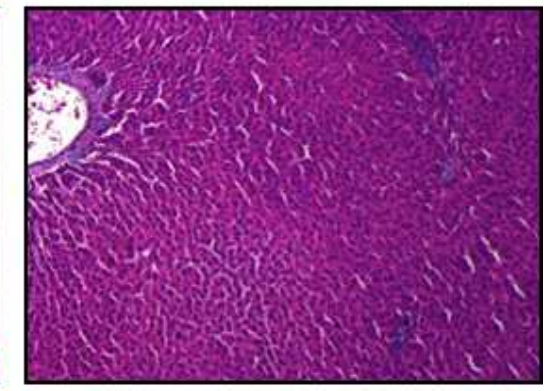

$\mathrm{F}$

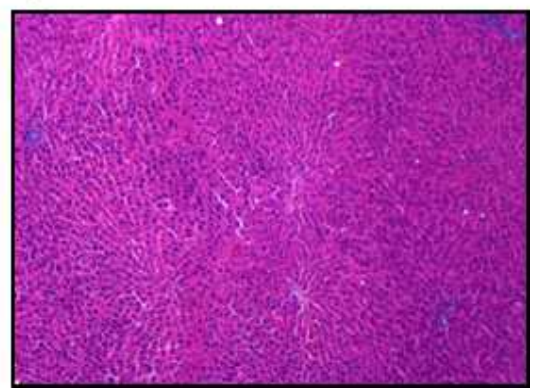

Fig. 3. Effects of ATSH on liver histology in rats treated with $t$-BHP. Liver sections were stained with hematoxylin and eosin (H\&E) and examined under a microscope.

A, normal control (NC) group; B, NC-2 (normal control $+2 \mathrm{~g}$ of ATSH); C, TC ( $t$ BHP-treated group); D, ATSH $(0.5 \mathrm{~g} / \mathrm{kg})$ pretreated group; E, ATSH $(1.0 \mathrm{~g} / \mathrm{kg})$ pretreated group; F, ATSH $(2.0 \mathrm{~g} / \mathrm{kg})$ pretreated group. 
synthetic process, and utilized more widely as protective agent of liver.

\section{Conclusion}

ATSH exhibited a protective effect against $t$-BHP-induced hepatotoxicity and liver damage by lowering AST, ALT and LDH in biochemical test of blood. However, hematologic indexes were not changed by ATSH treatment. MDA, which was increased in liver damages by $t$-BHP treatment, was also significantly decreased by ATSH. Glutathione, an endogenous antioxidant molecule, was greatly decreased, but recovered by ATSH treatment. ATSH effectively elevated the activities of GST, SOD, and catalase, which are antioxidant enzymes. These beneficial effects of ATSH on the hepatotoxicity and oxidative stress correlated to the histologic result of liver, which was recovered from $t$-BHP induced damages in hematoxylin and eosin (H\&E) staining. Thus, ATSH showed a potential to use as a natural hepatoprotective agent derived from silk protein.

\section{Acknowledment}

This work was supported by a research grant from Seoul Women's University (2017).

\section{References}

1. Kim J, Hwang H, Park J, Yun HY, Suh H, Lim K (2014) Silk peptide treatment can improve the exercise performance of mice. J Int Soc Sports Nutr, 11, 35

2. Lee SH, Cho BN, Han CK, Joo SS (2002) Physiologic functionality of silk peptides- focus on antioxidant and immune function. Food Science and Industry, 35, 57-61

3. Hwang E, Kang B, Kim B, Lee HJ (2001) Protein quality evaluation and effect of plasma lipid contents of acid hydrolysates of cocoon in rats fed by high cholesterol, high triglyceride and high sucrose diet. J Korean Soc Food Sci Nutr, 30, 1004-1009

4. Zhaorigetu S, Yanaka N, Sasaki M, Watanabe H, Kato $N$ (2003) Inhibitory effects of silk protein, sericin on UVB-induced acute damage and tumor promotion by reducing oxidative stress in the skin of hairless mouse. J Photochem Photobiol B, 71, 11-17
5. Kim AJ, Kim SY, Choi MK, Kim MH, Han MR, Chung KS (2005) Effects of mulberry leaves powder on lipid metabolism in high cholesterol-fed rats. Korean J Food Sci Technol, 37, 636-641

6. Kim DW, Hwang HS, Kim DS, Sheen SH, Heo DH, Hwang G, Kang SH, Kweon H, Jo YY, Kang SW, Lee KG, Park KW, Han KH, Park J, Eum WS, Cho YJ, Choi HC, Choi SY (2011) Effect of silk fibroin peptide derived from silkworm Bombyx mori on the anti-inflammatory effect of Tat-SOD in a mice edema model. BMB Rep, 44, 787-792

7. Abdel-Misih SRZ, Bloomston M (2010) Liver anatomy. Surg Clin N Am, 90, 643-653

8. Davis GL, Albright JE, Cook SF, Rosenberg DM (2003) Projecting future complications of chronic hepatitis $\mathrm{C}$ in the United States. Liver Transplant, 9, 331-338

9. Cesaratto L, Vascotto C, Calligaris S, Tell G (2004) The importance of redox state in liver damage. Ann Hepatol, 3, 86-92

10. Baud L, Ardaillou R (1993) Involvement of reactive oxygen species in kidney damage. Br Med Bull, 49, 621-629

11. Griffiths HR, Dowling EJ, Sahinoglu T, Blake DR, Parnham M, Lunec J (1992) The selective protection afforded by ebselen against lipid peroxidation in an ROS-dependent model of inflammation. Agents Actions, 36, 107-111

12. Halliwell B, Gutteridge JMC, Cross CE (1992) Free radicals, antioxidants, and human disease: where are we now?. J Lab Clin Med, 119, 598-620

13. McCord JM (1988) Superoxide dismutase: the first twenty years (1968-1988). Free Radic Biol Med, 5, 363-369

14. Meister A (1988) Glutathione metabolism and its selective modification. J Biol Chem, 263, 17205 - 17208

15. Spector A (2009) Review: Oxidative stress and disease. J Ocul Pharmacol Ther, 16, 193-201

16. Kim EY, Hong KB, Suh HJ, Choi HS (2015) Protective effects of germinated and fermented soybean extract against tert-butyl hydroperoxide-induced hepatotoxicity in HepG2 cells and in rats. Food Funct, 6, 3512-3521

17. Lock JF, Reinhold T, Malinowski M, Pratschke J, Neuhaus P, Stockmann M (2009) The costs of postoperative liver failure and the economic impact of liver function capacity after extended liver resection-a single-center experience. Langenbecks Arch Surg, 394, $1047-1056$ 
18. Kim JH, Suh HJ, Choi HS (2017) Protective effect of silk protein hydrolysates against tert-BHP induced liver damage. Korean J Food Preserv, 24, 107-115

19. Wang CJ, Wang JM, Lin WL, Chu CY, Chou FP, Tseng TH (2000) Protective effect of Hibiscus anthocyanins against tert-butyl hydroperoxide-induced hepatic toxicity in rats. Food Chem Toxicol, 38, 411-416

20. Reed DJ (1986) Regulation of reductive processes by glutathione. Biochem Pharmacol, 35, 7-13

21. Habig WH, Pabst MJ, Jakoby WB (1974) Glutathione S-transferases: The first enzymatic step in mercapturic acid formation. J Biol Chem, 249, 7130-7139

22. Aebi H, Suter H, Feinstein RN (1968) Activity and stability of catalase in blood and tissues of normal and acatalasemic mice. Biochem Genet, 2, 245-251

23. Durackova Z, Labuda J (1995) Superoxide dismutase mimetic activity of macrocyclic $\mathrm{Cu}(\mathrm{II})$-tetraanhydroaminobenzaldehyde (TAAB) complex. J Inorg Biochem, 58, 297-303

24. Lee HS, Won NH, Kim KH, Lee H, Jun W, Lee KW (2005) Antioxidant effects of aqueous extract of Terminalia chebula in vivo and in vitro. Biol Pharm Bull, 28, 1639-1644

25. Cassidy WM, Reynolds TB (1994) Serum lactic dehydrogenase in the differential diagnosis of acute hepatocellular injury. J Clin Gastroenterol, 19, 118-121

26. Chiang WD, Huang CY, Paul CR, Lee ZY, Lin WT (2016) Lipolysis stimulating peptides of potato protein hydrolysate effectively suppresses high-fat-diet-induced hepatocyte apoptosis and fibrosis in aging rats. Food Nutr Res, 60, 31417

27. Chung YI, Bae IY, Lee JY, Chun HS, Lee HG (2009) Protective effects of branched-chain amino acid (BCAA)-enriched corn gluten hydrolysates on ethanolinduced hepatic injury in rats. Korean J Food Sci Technol, 41, 706-711

28. Kamoun Z, Kamoun AS, Bougatef A, Kharrat RM, Youssfi H, Boudawara T, Chakroun M, Nasri M, Zeghal
N (2017) Hepatoprotective and nephroprotective effects of sardinelle (Sardinella aurita) protein hydrolysate against ethanol-induced oxidative stress in rats. Environ Sci Pollut Res Int, 24, 1432-1441

29. Draper HH, Hadley M (1990) Malondialdehyde determination as index of lipid Peroxidation. Method Enzymol, 186, 421-431

30. Han BK, Park Y, Choi HS, Suh HJ (2016) Hepatoprotective effects of soluble rice protein in primary hepatocytes and in mice. J Sci Food Agric, 96, 685-694

31. Cai X, Yan A, Fu N, Wang S (2017) In vitro antioxidant activities of enzymatic hydrolysate from Schizochytrium sp. and its hepatoprotective effects on acute alcoholinduced liver injury in vivo. Mar Drugs, 15, 115

32. Lushchak VI (2012) Glutathione homeostasis and functions: potential targets for medical interventions. J Amino Acids, 2012, 736837

33. Nasri R, Abdelhedi O, Jemil I, Daoued I, Hamden K, Kallel C, Elfeki A, Lamri-Senhadji M, Boualga A, Nasri M, Karra-Chaabouni M (2015) Ameliorating effects of goby fish protein hydrolysates on high-fat-high-fructose diet-induced hyperglycemia, oxidative stress and deterioration of kidney function in rats. Chem Biol Interact, 242, 71-80

34. Han CH, Lin YF, Lin YS, Lee TL, Huang WJ, Lin SY, Hou WC (2014) Effects of yam tuber protein, dioscorin, on attenuating oxidative status and learning dysfunction in D-galactose-induced BALB/c mice. Food Chem Toxicol, 65, 356-363

35. Pacheco MTB, Sgarbieri VC (2005) Effect of different hydrolysates of whey protein on hepatic glutathione content in mice. J Med Food, 8, 337-342

36. Guicciardi ME, Malhi H, Mott JL, Gores GJ (2013) Apoptosis and necrosis in the liver. Compr Physiol, 3, 977-1010

37. Rock KL, Kono H (2008) The inflammatory response to cell death. Annu Rev Pathol: Mech Dis, 3, 99-126 